\title{
Existence and Negativity
}

The Relevance of the Patočka-Bergson Controversy over

\section{Nothingness}

Jakub Čapek

Journal of French and Francophone Philosophy - Revue de la philosophie

française et de langue française, Vol XXIX, No 1-2 (2021) pp 22-47

\author{
Vol XXIX, No 1-2 (2021) \\ ISSN 1936-6280 (print) \\ ISSN 2155-1162 (online) \\ DOI 10.5195/jffp.2021.986 \\ www.jffp.org
}

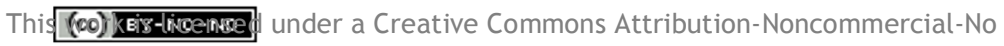
Derivative Works 3.0 United States License.

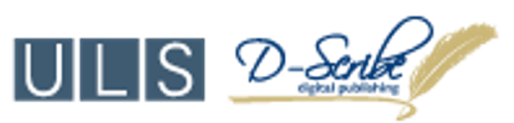

This journal is operated by the University Library System of the University of Pittsburgh as part of its D-Scribe Digital Publishing Program, and is co-sponsored by the University of Pittsburgh Press 


\title{
Existence and Negativity
}

\section{The Relevance of the Patočka-Bergson Controversy over Nothingness}

\author{
Jakub Čapek \\ Charles University
}

Jan Patočka should have a prominent place among philosophers who emphasized the essentially negative character of human existence." This holds true at least for reflections he wrote in the second half of the 1940s. ${ }^{1}$ Patočka thus found himself in the neighborhood of Sartre's existentialism, Heidegger's philosophy of being, and Hegel's dialectic, and at the same time in opposition to schools of thought which either completely reject the substantive use of "the nothing," such as Carnap's positivism, or relativize it, like Bergson. It is the latter polemic, Patočka's polemic with Bergson, which I will discuss in some detail here. This encounter sheds some light on the meaning of negativity in Patočka. In his thinking, the concept of negativity basically refers to the idea that human existence is defined by a capacity to adopt a distance toward what is pre-given, be it the reality of the physical world or the established habits and rules of a particular society. Negativity qua distance has in Patočka an absolute character. It is this claim that he defends in his critique of Bergson.

The main part of my article attempts to reconstruct Patočka's position. I claim that the wager on absolute negativity-in a meaning yet to be determined—does not make Patočka a nihilist, and that is for one particular reason: the interest in negativity is paralleled by a sustained philosophical interest in the concept of totality, be it the totality of one's own life or of the surrounding world. Patočka is thus not a nihilist, but a philosopher of a negative holism, and, in a sense, even a moralist. Above and beyond a reconstruction of Patočka's stance, I will spell out some reservations I have. Patočka's negative holism makes frequent, yet somewhat indiscriminate use of the category of "negation," tending to downplay important distinctions. It is, to give but one example, objectionable to call a "horizon" of a perceived object or its hidden side its "negation." But, more important, what is the systematic meaning of Patočka's recourse to negativity? Is negation really 
what is at stake-even for Patočka? I will suggest that negation is not everything, and that, taken separately, it is not even absolute. Negation is an indispensable part of a more complex existential structure Patočka is aiming at. The terms he uses for this structure include "thirst for the absolute," "thirst for reality," "restlessness of the heart," and "desire." To translate these allusions onto a general plan, it is useful to talk about the capacity to establish differences that matter. As general as it seems, this turn of phrase can grasp both Patočka's emphasis on negativity, and his emphasis on the absolute, the latter, nevertheless, not residing in a distance from being, but in differences established, maintained, and abandoned by ourselves within being.

I suggest that one read the reflections that Patočka developed in these essays as his pursuing at least two interrelated, yet distinct tasks. First of all, Patočka embarks on a philosophical anthropology which-in close proximity to the philosophy of existence-attempts to grasp the "essence of humanity." ${ }^{2}$ What is more, in Patočka this task leads straight into ethics. The task of philosophy, however, is not merely to define human existence and draw conclusions for ethics, but also to "think the world." Thus, apart from the ethical orientation, Patočka makes an "attempt at an ontology on existential grounds." 3

The elaboration of the first task is defined by Patočka in detailed polemics against value relativism and nihilism on the one hand, and against value objectivism on the other. While Patočka associated value relativism, for instance, with Sartre, he identified value objectivism with various versions of Platonism, be it with Plato himself or with Max Scheler and Emanuel Rádl. The ethics formulated by Patočka seeks to break out of this duality between relativistic ethics, whereby values are determined by individual subjects, and ethical objectivism, which attributes real existence to values. ${ }^{4}$ For him, the human capacity to negate partial goals pursued by an individual in the course of his or her life plays a key role in overcoming this duality. Alluding to Saint Augustine, Patočka speaks of the restlessness of the heart, or the "absolute thirst" of the heart, on the basis of which he characterizes human existence as "non-satisfaction by every finite, positive goal. It is the consciousness of the relativity of every concrete goal." ${ }^{5}$ Patočka interprets Socrates' knowledge of not knowing precisely as the negation of partial ends. It is thanks to the knowledge of not knowing that we depart from every relativism and pursue "an internal unity and concentration of life." 6

The second philosophical task to "think the world" aims at showing that the way human existence relates to its environment is the basis for a theory of knowledge and ontology. Patočka contends that consciousness is indispensable for any objective knowledge, which puts him against various versions of materialism and in line with more subjectivist philosophies. At the same time, he opposes versions of the philosophy of subject which would describe human experience as a passive process taking place within the subject and with no claim to objective validity. Though we experience the 
world from a certain point of view, always perspectively and partially, our knowledge exhibits a priori structures. For example, our embodied ability to focus on a perceived object and to isolate it from its surroundings is one such a priori. ${ }^{7}$ In developing this position, drawing on selected motifs from Husserl's and Merleau-Ponty's phenomenology, Patočka emphasizes the human capacity to connect what is present with what is absent, for example, with the still unseen parts of an object. Characteristically, for Patocka the experience of perspective is an experience of negativity:

Perspective is an Urphänomen, one of the great speculative experiences: that in the finite the non-finite is given, that the finite is possible only in the non-finite, that the present is [conceivable] only as a view of the absent, that nothing is just identical to itself-what a source of wonder here. The negative moment in perspective: perspective means that the "positively given" is only a tiny part of the negatively given, that the absent, the indirect, has an immense preponderance. ${ }^{8}$

Within the task of "thinking the world," the philosophy developed by Patočka again emphasizes negativity. For Patočka, the a priori component of our relation to the world consists not primarily in the positive structuring of phenomena, for example, according to the figure-background form, but "in distancing from the object." He describes the a priori of our contact with things as "the creation of a spatium in which the encounter with the concrete can take place," which leads him explicitly to espouse a negative conception of the a priori. $^{9}$

The philosophical project pursued by Patočka highlights negativity both in ethics - as non-satisfaction by finite ends-and in the theory of knowledge and ontology, where it becomes the distance through which we gain any access at all to things. By placing negativity and nothingness at the center of his attention, Patočka comes close to authors such as Sartre, Heidegger, and Hegel, but, conversely, very far, at least in this respect, from Bergson, who considers the philosophical problem of nothingness a pseudoproblem. In his unpublished essay "Nothingness, Absolute Position and Negation" (1947 or 1948), ${ }^{10}$ Patočka develops a sustained critique of Bergson precisely on this point.

Patočka valued Bergson's philosophy highly from his early writings on. Though he wrote The Natural World as a Philosophical Problem (1936) from the position of Husserl's phenomenology, Patočka makes frequent use of the notion of life, and in its conclusion even uses Bergson's term "creative evolution" to label the task of reconstructing the history of the human world. ${ }^{11}$ Similarly, Patočka's wartime manuscripts hover close to the philosophy of life. ${ }^{12}$ But in Patočka's philosophical project of the second half of the 1940s, we no longer find vitalist elements. The explicit polemic with Bergson thus has 
several meanings. It is evidence of a break in Patočka's relationship with vitalism; it is an important text in which Patočka formulates his conception of negation and nothingness; and it is one of the few texts in which his emphasis on negativity is developed not only in the ethical, but also in the ontological context. Let us start, then, by restating Bergson's account of nothingness.

\section{Bergson: Nothingness as a Pseudo-problem}

Bergson claims that the concept of absolute nothingness implies a contradiction. Consequently, Leibniz's question of why there is something rather than nothing at all turns out to be a pseudo-problem. For Bergson, the seemingly simple notion "nothing" always contains at least two components: the idea of replacing one thing with another and the feeling of regret we associate with the replacement. For example, when we take a guest through a room that has not yet been furnished, we may very well say that there is nothing in it. We both know that the room is full of air, but, as Bergson points out, we can hardly sit on it. The nothing we have in mind is nothing to sit on. In this precise and relative sense, the notion of nothingness is well justified. We encounter nothingness only in the realm of human action, and it is always a relative nothingness, relative to what could be in a given place, relative to what we might wish for instead of what is there. As Bergson puts it, "in this quite relative sense ... we are constantly going from the void to the full."13 Importantly for Bergson, the two elements that make up the idea of nonbeing are both positive: in ourselves, we find a feeling of regret, which is positive because it is de facto an expectation, a preference, a wish, a desire; and in the world that lacks something, we find a substitute-namely, the presence of a thing different from the thing that could have been there.

This gives Bergson's notion of nothingness a more precise contour. Nothingness, the nonbeing (le néant) does not mean the opposite of being. In this, Bergson is close to Plato's Sophist dialogue, where nonbeing is "not the opposite of being, but only the other of being" (not enantion, but heteron; Soph. $258 \mathrm{~b}$ ). If we say that something is not great, we are not thereby saying that it is nonexistent. On the contrary, it does exist, yet is something other than the great. Similarly, for Bergson, the "partial nought" (le néant partiel) consists not in the fact that a thing is replaced "by a void which it leaves, that is, by the negation of itself," but in the fact that it is replaced by another thing. ${ }^{14}$ Nothingness is denied the potential to negate the existent, to be its opposite (enantion), and is converted into a relation of difference to it (heteron ekeinou). It is thus possible to speak of "nonbeing" without claiming that a void has appeared in being.

Bergson defends this conviction in his discussion of affirmative and negative judgments. A negative judgment is not the symmetrical opposite of an affirmative judgment; it is not a judgment by which we deny the existence 
of a thing or deny it a property. A negative judgment is an affirmative judgment of the second order: the sentence "this table is not white" refers (a) to a judgment that someone has made or could make about the table in front of us (namely, that it is white), (b) and asserts that something else will have to be said about the table in question other than attributing to it the property "white." By making a negative judgment, we are positively communicating to someone-whether to ourselves or to another-that "he ought to affirm something else (though without specifying the affirmation which must be substituted)."15 A negative judgment is social in nature, a warning of possible error, of the "need of substituting for an affirmative judgment another affirmative judgment."16 By negative judgments we do not deny that something exists, but seek to prevent or correct mistakes about our knowledge of what is.

We do experience the absence of things and pronounce negative judgments, yet we should not draw unjustified conclusions from this. First, we should not assume that there is nothingness in the world if by this we mean nonbeing posited against being. In the world, we constantly encounter existing things, and the nothingness we find in the world is not the absence of things. What we encounter is "the absence not so much of a thing, as of a utility." 17 Second, the idea of nothingness understood as the absence of the utility of an existing thing cannot account for the idea of absolute nothingness. If we generalize this partial nonbeing (the "partial nought") — which is in fact a being that has no use for us - and conceive the idea of absolute nothingness (as the absence not of one but of all things), the result is a contradiction. For if nothingness implies the substitution of one thing for another, then the removal of everything is inconceivable. The notion of absolute nothingness is self-destructive. The question of why there is anything at all, rather than nothing, is a pseudo-problem based on a fundamentally flawed notion of negation, void, and nonbeing. ${ }^{18}$

Bergson's critique of nothingness constitutes an important part of a philosophy that understands reality as an ever-changing creation of the new. We cannot understand reality as the unpredictable emergence of the new as long as we project into it habits taken from the realm of action. If we free ourselves from these concerns of utility, we acquire an enlarged perception and touch the absolute: "the Absolute is revealed very near us and, in a certain measure, in us. . . . It lives with us." ${ }^{19}$ In Bergson's philosophy, the absolute can be immediately given. Patočka is heading toward a philosophy in which the absolute is never immediately given, but resides, on the contrary, distant from the given, in the denial of being, that is, in nothingness. 


\section{Patočka's Polemic with Bergson}

Before Patočka discusses Bergson's position, which "seems so clear that it cannot be objected to," ${ }^{20}$ he gives a brief overview of the conceptions of nothingness in Heidegger, Sartre, and Hegel. This overview fulfills a dual function. First, Patočka lists the grounds on which one might object to Bergson's doctrine. Second, he reflects on whether he himself would use these to disagree with Bergson. To each of the conceptions of nothingness reported here, Patočka adds a critical commentary, showing why he does not fully identify with any of the alternatives to Bergson's view.

Patočka appreciates that Bergson draws attention to the practical and emotional context of our experience of nothingness, but considers Heidegger's account of anxiety to be a more consistent elaboration of this "feeling of nothingness." In deep anxiety, we experience how none of the objects around us offers us support and refuge. Nothingness, which refers here to "the insignificance of all objects," confronts us explicitly with the question of our own being: "the fact of being becomes urgent, conspicuous." The question for Patočka, however, is whether what the experience of anxiety reveals is "indeed absolute nothingness" rather than "pure being." 21 Similarly, Sartre's doctrine is an important elaboration of the "experience of nothingness," but in Sartre it is linked to a particular notion of consciousness. Sartrean consciousness brings nothingness into the world because, as consciousness of itself, it is internally divided. Patočka distrusts Sartre's thesis of an internally split consciousness, which lives in disunity with itself and projects this lack of being outside itself. ${ }^{22}$ Concerning Hegel, Patočka admits that his dialectic could introduce contradiction and drama into philosophical reflections about nothingness. For Patočka, however, the dialectic is ultimately a static structure, and, more importantly, negation and nonexistence in the dialectical process is only "transitory and apparent." ${ }^{23}$ In his critique of Bergson, Patočka does not rely on Hegelian dialectics, Sartre's concept of consciousness, or Heidegger's analysis of anxiety.

Patočka's objections to Bergson can usefully be summarized as three main ideas. First, Bergson does not offer a plausible analysis of our relation to things and changes which surround us and always combine presence with absence. Second, Bergson underestimates the negative character of some emotions and is completely wrong when claiming that negative emotions can be converted into positive desire. Third, while rejecting the idea of absolute nothingness, Bergson works with the notion of the whole as the sum of the parts, which is unacceptable. Patočka offers an alternative rethinking of the relationship between nothingness and the whole: in order to conceive of the whole at all, we must transcend it. 
(a) Our relation to things and their changes: givenness is always a correlate of non-givenness.

The first set of objections rests on the observation that a plausible account of the human relationship to things and their transformations always connects the present and the absent. In perception, a thing stands out against its background; it has a back side that is not given but could become the object of our perception. Patočka sometimes refers to the context or "horizon" of a thing as its negation, and it is important for him that we have here a case of "negation of a certain being without substitution by another being," that we have an absence as part of our perception. ${ }^{24}$ Concerning the absence of the unseen side of a thing, Bergson would account for it on the basis of the model of substitution. This, however, Patočka finds insufficient: "the negative is not simply there by virtue of this substitution, but the substitution as such, the substitution of distinct individualities already presupposes a negative element, the presence of absence, the negative givenness as something original." 25

Not only perception and our capacity for perceptual discrimination, but also recollection and imagination demonstrate that non-reality cannot be explained by the idea of substitution. ${ }^{26}$ In general, the distinction between the real and the non-real "cannot come from pure realities, which are always positive." 27

Bergson might reply to Patočka that the perception separating and then connecting the given and the not-given is characteristic only of our ordinary, practical concerns, that "distinct perception is merely cut, for the purposes of practical existence, out of a wider canvas." If we nevertheless expand our perception, we find "that reality is change, that change is indivisible, and that in an indivisible change the past is one with the present." ${ }^{28}$ Patočka, however, makes a rather harsh observation concerning Bergson's idea of expanded perception. It is, he writes, a naive "pan-aesthetic ideal," which was already rejected by Aristotle and, in another context, by Husserl, and "is in fact an ideal of utter stupidity." 29

The decisive argument, however, is built by Patočka on a different analysis of change. The substitution of one thing for another presupposes that we hold the two things together, that is, within a common dimension. Moving from one reality to another presupposes something "in the face of which, in relation to which, both stand on the same level," and this something cannot itself be reality again. ${ }^{30}$ At one point, Patočka calls this "something" the temporal dimension. Nevertheless, he does not want to hastily identify the environment in which we grasp the substitution of one thing by another with linear time. Instead, he speaks of perspective. In one remark, it is perspective that is declared to be that dimension "within which" things alternate, a dimension that is "itself nothing real." ${ }^{31}$ Regardless of whether we call time, 
the horizon, or perspective the dimension of substitution, it is always something that is neither actual nor fully present. ${ }^{32}$

Following his observation that in our relationship to surrounding things and changes we always associate being and nonbeing with each other, Patočka rejects Bergson's interpretation of negative judgments. The claim that a negative judgment is an affirmative judgment of the second degree deprives negative judgment of a direct relationship to things. Perception is already imbued with negativity, for it connects being with nonbeing. The same is true of negative judgments, whether we distinguish one thing from another or state that one thing has been replaced by another and no longer exists. Both the distinguishing negation ( $\mathrm{A}$ is not $\mathrm{B}$ ) and the suppressing negation (B) instead of (A) relate to things, not merely to another judgment: "negation quite obviously expresses a relation among things, and not merely a relation to a possible judgment." 33 Negative judgments are about things and their relations, not judgments about other judgments. For Patočka, negativity-be it perceptual negativity or negativity in judgments—refers to reality. ${ }^{34}$

(b) Bergson downplays emotional negativity.

Regret, which constitutes part of our experience of nothingness, is for Bergson not a negative emotion, but a positive desire for something that is not given in the present reality. Patočka thinks that Bergson underestimates the negative character of some emotions and that he is completely wrong to claim that lacking something can be completely rephrased in terms of a positive desire.

What is involved in desire is not merely the experience that what is present is different from what I desire (as Bergson suggests it is), but the experience that what I desire is not present, and what is present, is insufficient. Negativity cannot be smoothly converted into a relationship of difference. "Desiring, lacking, is ipso facto something negative: the consciousness of the absence of something, and this consciousness is wholly original and irreducible." 35 Only by admitting that lacking does have a negative character can we explain why we experience substitution, that is, the presence of a thing different from what is desired, as nothingness. As Patočka points out, Bergson himself thus implicitly presupposes the negative character of desire.

At this point, it would suffice to show that however positive desire may be, the negative element cannot be completely removed from it, at least not until it is a satisfied desire. Patočka, nevertheless, goes even further in his discussion of the negativity present in some emotions. He draws attention to emotions that are purely negative, to the "emotional denial" that we experience in dislike, aversion, disgust, or pain. Such a denial is distinguished, for example, from fantasy, which makes us see the possible, which is 
contained in the given, or from desire, which makes us see or feel an absence in the given. "Emotional denial," argues Patočka, "means nothing other than I do not accept." 36 True, Bergson also mentions "dissatisfaction," 37 but it is a dissatisfaction motivated by an unfulfilled desire for another thing. Patočka believes there is a dissatisfaction in which we do not seek to be satisfied by something else. Our affectivity includes not only attitudes such as a frustration that seeks satisfaction elsewhere, but also such emotions that consist only in defiance, in protest. There is a kind of negation which is not positive striving; there is a denial without a substitute.

(c) In criticizing the notion of "absolute nothingness," Bergson presupposes an erroneous notion of the whole.

Bergson's proof-namely, that the notion of absolute nothingness is selfcontradictory-is based on the assumption that we cannot generalize partial negations. Every negation is essentially a substitution, and one cannot justifiably conceive of the substitution of everything. Patočka points out that Bergson's reasoning is already problematic the moment he speaks of the whole. According to Bergson, we form the concept of the whole or of the all (le tout) in the following way: "By affirming one thing, and then another, and so on ad infinitum, I form the idea of 'All.'" 38 Patočka refuses to follow Bergson in this step. Bergson's philosophy lacks the concept of the world, the whole, the universe: "We have only a general concept of all existing realities, but not the universe as one all-encompassing individuum. ${ }^{\prime 39}$ Not only is it impossible to conceive the negation of the all as a gradual negation of parts going to infinity, but the whole, the all, cannot be thought of as merely a collection of parts.

Here Patočka draws on the phenomenological analyses of the whole which are to some extent developed already in the first objection: the horizon of a thing cannot be derived from the thing, the dimension in which the thing appears (spatial and temporal perspective) is not derivable from the thing and yet is essential to it. Here we are making an experience of a more encompassing whole that is not the sum of its parts. "The whole is not the sum of the parts" is familiar to Patočka from both Husserl's and Heidegger's philosophy and forms a recurring motif in The Natural World as a Philosophical Problem: "the unity of the world is not the unity of the materials composing it." ${ }^{40}$ In the 1930s, however, Patočka defends the idea that the human spirit is the necessary world-making agent. The sentence I have just quoted continues: the unity of the world is "the unity of the spirit that shapes and sustains it." In the second half of the 1940s, however, it is not the notion of spirit but the notion of negation which is crucial for conceiving of the whole: if we are to conceive of the whole, we must transcend it, we must step outside being. While Bergson raises the merely rhetorical question, "How then can the idea of Nought be opposed to that of All?" ${ }^{41}$ Patočka argues that we must do just 
that: through nothingness understood as the negation of being in its totality, we can relate to the whole. Not only is it possible, it is even necessary to conceive the idea of nothingness and the idea of the whole of being as defined by their contraposition. This systematic linking together of the concepts of nothingness and the whole forms one of the main motifs of Patočka's reflections.

\section{Patočka's Negative Holism}

For Patočka, the capacity to relate to the whole is a salient feature of human existence as distinct from the life of animals or the existence of things. Whereas in The Natural World Patočka strives from the very first pages to give a positive account of the unity of the world, after World War II he regards the "doctrine of the whole" as a metaphysical theory that is no longer tenable. A philosophy that neither forgets the human relationship to the whole, nor transforms it into a metaphysical doctrine can approach the whole only negatively. ${ }^{42}$ In this period of Patočka's thought, nothingness and negation enjoy a privileged position not because of some temporary inclination toward nihilism. Nothingness paradoxically offers itself as a non-metaphysical possibility of a holistic relationship. Patočka's negative philosophy is not nihilism but, so to say, negative holism.

Following our initial distinction between the two directions of Patočka's philosophical preoccupations here, we should explore his negative approach to the whole separately in two main areas, ethics and ontology. Although rough, the distinction is important, because the relevant concept of the whole is each time different: one time the whole of human life is at stake, the other time the whole of reality. Thus, the questions that arise are also substantially different. Similarly, negation assumes a different role each time.

\section{(a) Negativity and the totality of life}

To the extent that he focuses on individual self-accomplishment, the whole that Patočka is concerned with is "individual human destiny." 43 This whole can only be aimed at by problematizing the individual goals we pursue; it cannot be aimed at directly. Patočka links the capacity to distance oneself from the individual goals one pursues in life to an Augustinian restlessness of the heart, adding:

this absolute thirst is not just something negative. It is a dissatisfaction with every finitude, with every positive goal. It is the consciousness of the relativity of every concrete goal. And yet only in fidelity to concrete goals does this negativity manifest itself positively. . . . Not absolute relativism, but relative absolutism. Never to lose 
the thirst for the absolute is to introduce the absolute into the relative. And that is the only way the absolute can live, the only way the world can make sense. ${ }^{44}$

If the notion of the absolute can be preserved in the current post-metaphysical situation, more precisely in philosophical ethics, it can only be achieved negatively. Nothingness is the last absolute we have left. When Patočka speaks of "givenness" in ethics, it is not the givenness of individual things or facts, but the givenness of the goals we have adopted for our lives, of traditions, habits, and routines. ${ }^{45}$ "Negativity" here consist in the capacity to break out of this givenness and to see these goals as insufficient, to regard a life that is led habitually, unreflectively, as a life afflicted by negativity, as but a semblance of a true life. "Dissatisfaction with every finitude" thus turns out to be positive. It is the negation of the apparent, the overcoming of the negativity of the unreflected life, the negation of negation. Patočka uses the vocabulary of Hegel and Marx, for whom the negation of negation is the "overcoming of alienation." From a purely formal point of view, Socrates' striving is a negation of the same type: "The negation of negation is also Socrates' concern for the soul." 46 Thus, the knowledge of not knowing and the negation of all partial goals is reversed into a positive choice of being: "by rejecting relative goals [. . .], we achieve a concentration of life and a return from negativity to positivity, to full being." 47 This does not mean that Patočka's ethics presents a positive solution for the individual existence to follow. If one can speak of a solution at all, it consists in relentless questioning: "the solution is in the question that becomes the form of life." 48 Yet in a sense we do get beyond constant negation; we leave the "bad infinite,"49 and through negation we achieve a way of life which Patočka characterizes in highly positive terms such as "life concentration," "fullness of being," "true being," and "self-accomplishment." 50

\section{(b) Negativity and the totality of being}

Philosophy for Patočka also entails the task to "think the world." The cosmological concept of the whole enters the scene. The term "givenness" no longer refers to a life-goal or a socially recognized routine, but to an individual entity, a thing or a fact we encounter. Negation here does not take the form of a rejection of partial goals and established habits, but of "cosmic nothingness," a turn of phrase Patočka uses somewhat loosely to describe the nothingness uncovered in Heideggerian anxiety. The first thesis of this cosmology states that if we are to relate to the whole, we must transcend it without denying it:

The idea of the whole must, in a sense, go beyond this whole. Thus, the whole presupposes not only existing things, realities, but also the transcensus of existing things without their denial. But this transcending without denying 
is necessarily a transcendence to non-being [. . . .] Nothingness is the unsatisfactoriness in the given being, the demand of the not-given. ${ }^{51}$

Patočka makes immediately clear that we do not arrive at this nothingness from the Bergsonian understanding of nothingness as the replacement of one being by another: "by negating the [particular] being we do not arrive at nothingness. Nevertheless, we do have a relation to being in totality; there must therefore be another negation than the negation of a particular being by another particular being." ${ }^{52}$

This general thesis about nothingness, which consists in the negation of the whole of being, is complemented (in the course of the polemic with Bergson) by at least one consequence: it is precisely thanks to the capacity for total distancing ourselves from being as such that we are able to establish partial distances within being. It is because we can distance ourselves from being in general that we can establish partial differences between things, penetrate into their relationships and offer an interpretation of them. "The fact that we are not satisfied by the given, by the factual, the finite," according to Patočka, manifests itself "also in the fact that we are unsatisfied by a particular given and the factual. (1) The effort to penetrate further into the factual. (2) The effort to analyze, dismantle the factual. (3) The effort to interpret the factual, to find its basis." 53 The "no" uttered over being in general is the presupposition of all differentiation. In other words, the first precondition of understanding is negation. Reason presupposes the "negation of the given" which Patočka, nevertheless, also calls a desire or "thirst for reality." 54 This assertion-that it is through total distance from being that we are capable of partial differentiations within being-allows Patočka to conceive of his holistic negation as a positive step: total distance allows us to relate to being; it is an "ontological circumscription: away from being, back to being." 55 Negation is the condition of encountering.

\section{What is Negation?}

Patočka derives nothingness from negation. Absolute nothingness makes sense only when linked to the negating process, not as a state of utter emptiness or nonexistence, the meaninglessness of which Bergson denied. There is no nothingness without negation. Patočka distinguishes between partial negation on the one hand and total negation on the other. He distinguishes two kinds of partial negation: negation that distinguishes (negatio distinctiva, negation of difference) and negation that suppresses (negatio suppletiva, negation of contradiction). ${ }^{56}$ Under the distinguishing negation, if I understand Patočka correctly, falls any determination of the differences between two things. Under negation of contradiction falls replacement of one thing by another one, or a conflict of two forces in which 
one prevails over the other. One thing is not only different from another, but is chased from being by another.

Patočka considers the active, suppressing, "contradicting" type of negation to be more important for the very concept of negation. What is more, he suggests that the "contradicting negation" does not have to consist in replacing one thing with another; it can be negation without replacement. He uses a number of synonyms for this latter type of negation, including resistance, defiance, distance, rejection, and protest. Moreover, he proposes to generalize this antithetical negation without replacement, that is, to relate it to the whole of reality. In this way, our experience of contradictions arrives at "something general-at the idea of the negativity of objective being in general." 57

An obvious question is where this total negation comes from. Given what we find in the Patočka essays examined here, we can say that stepping outside of reality altogether is a defining feature of consciousness. ${ }^{58}$ It seems that this negation is not an act that we may or may not perform. Being an a priori structure of our existence, it is something through which we gain access both to ourselves and to the reality around us. Patočka makes this point particularly forcefully by emphasizing the affective and involuntary character of the negation. To underscore the non-optional nature of the transcendence we always perform, he highlights the role of "emotional denial" in his polemic with Bergson and the role of "negative affection" in Eternity and Historicity. ${ }^{59}$

The stepping beyond being, the distancing oneself from the given, translates into the two basic tasks assumed by Patočka's philosophy: an ontological task and an ethical one. Transcending reality can explain both our relating to the world ("intentional sense-making") and our "moral life," which for Patočka is "the first, practical understanding of a fundamentally negative feature of our essence. ${ }^{\prime 60}$ It is one thing to negate the partial goals of life (which is the presupposition of life's unification) and another to experience dissatisfaction with the given (which is the precondition to any discriminating knowledge of reality). Both types of negation are, however, grounded in the structure of consciousness as a negation of the given.

The question necessarily arises whether Patočka's conception, despite his distrust concerning the formality of Hegel's dialectic, is not ultimately dialectical, that is, based on the mutual and dynamic interdependence of the positive and the negative. Even for Patočka himself, the consciousness that negates the given is to be characterized by a "dialectic of negative affection and fully positive being." 61 In this dialectic, however, the "no" is not related to the "yes" in order to form a new synthesis. There is no Aufhebung in Patočka. He even uses vocabulary that is, rather, reminiscent of the predialectical phase of German idealism when he speaks of consciousness that posits itself by the negation of the object. ${ }^{62}$ 
Before we consider the possible problems of the doctrine of negativity as a defining feature of consciousness, let us interpose an observation on how the philosophy of Patočka and the philosophy of Bergson relate to each other. This will provide some interesting insights, though the differences between the two positions are fundamental and any comparison at this point can only be general.

\section{Bergson versus Patočka: the Absolute as Creative Becoming and the Absolute as Negation}

Bergson's philosophy and Patočka's postwar philosophy can be seen as two inverted conceptions of the absolute. For Bergson, the absolute is creative becoming. Patočka himself accurately captures this idea when he claims that for Bergson "the absolute can exist in temporal form (as duration)." 63 The basic state of mind of the philosophy of creative becoming is joy.

Patočka does not embrace the absolute of creative becoming, but the absolute of negation. In the "thirst for the absolute," every particular entity is insufficient, every attained goal is relative. The basic state of the philosophy of absolute thirst is non-satisfaction. For Patočka, only an absolutely unsatisfied being can relate to reality, can penetrate it, for only through the constant possibility of distance does it have the ability to make any distinctions at all. The inexhaustible distance is neither escape nor relativism, because it is only on this ground that a discriminating attitude toward entities and the advocacy of partial goals are possible.

For both thinkers, the absolute is the source of human freedom. Bergson aligns freedom with creativity, not with deliberation and choice. Patočka also refuses to consider the choice between alternatives to be the main form of freedom, not in order to weaken the motif of distance, but in order to radicalize it: while in choice we choose between one and the other option, that is, we work with difference (negation is the "distinguishing negation" here), in transcending we act out the "neantization," the "negation of contradition," the simple "no." Freedom is not "creative becoming" within being, but a rupture with being, a withdrawal from being, a protest. Both the absolute of creative becoming and the absolute of the "no" that is uttered over being as such implies that choice and decision-making is not the key element of freedom. ${ }^{64}$ For Bergson, the core of freedom is the union with "élan vital"; for Patočka, it is the extrication of the human being from thoughtless immersion in given reality.

Still, Patočka and Bergson situate freedom outside the phenomenon of choice for utterly different reasons. Only Patočka's conception of freedom implies an extreme amplification of the chasm that separates the human being from all other entities, be they animate or inanimate. Patočka is thus an ardent 
supporter of anthropological difference. Only the human being, "unlike any other animal," exists "at a distance from reality in its totality." 65

\section{Conclusion}

Patočka's philosophical position in the second half of the 1940s raises a number of objections. The first problem is the indiscriminate use of the concept of "negation." In connection with the notion of horizon, Patočka succeeds in showing that every perception includes the non-present. But the very designation of the horizon as the "negation" of the thing poses a problem. Although the horizon cannot be derived from the given thing, it is not necessarily the negation of it, but a dimension of its appearing. Similarly the back side of the present object is the not-yet-given of this very thing, the present possibility of a future presence, so it is misleading to label it a negation of the given. ${ }^{66}$ Even if it is true that in our perception we always transcend the given, it does not follow that we must negate the given entity in order to perceive it, nor does it follow that we must transcend being as a whole. The real challenge for a reader of Patočka lies in his rapid transition from partial negation to total negation (and back).

The second problem is the claim that the ability to make distinctions derives from the universal ability to negate. This is a variant of the thesis "omnis determinatio est negatio," or rather of its Sartrean reinterpretation, "every negation is determination," which Sartre develops in admirable detail in Being and Nothingness for quantitative properties of things. ${ }^{67}$ And Patočka seems to make a similar assumption: at the basis of every individual difference is negation. But the claim that all distinctions are negations and that partial negations are grounded in total negation ${ }^{68}$ requires a more detailed justification, which is not found in Patočka.

The third problem that Patočka's project raises is that it considers all nonhuman beings as indifferent. Patočka explicitly speaks of the "indifference of the utter outwardness" of non-human entities. It is up to us "to substitute our lives for their essential shortcoming." ${ }^{69}$ A non-human being, for example, if left to itself, stands in no relation to time unless it is introduced into temporality by a human being. ${ }^{70}$ A philosophy that characterizes humanity by the exclusive capacity for absolute negation radically distances humanity from anything that lacks this capacity.

What have we gained by wagering on absolute negation? In the realm of ethics, this wager should have guaranteed us a break from value relativism, but without having to espouse value realism. Despite Patočka's assurances, the question remains, how exactly the relativization of all partial goals leads not away from the pursuit of any goals but back to them; how does it "introduce the absolute into the relative." Patočka's explanation of why his absolutist move is not a relativization lies in proposing the possibility of a life 
for which living in problematicity becomes a "form of life." Still, we might well conceive of a philosophy of relative ends that would give more weight to the choice or conflict of those particular ends, while preserving the tension of life that Patočka is ultimately after, without resorting to the notion of the negative absolute. In the realm of ontology, the benefit of the wager on transcendence in relation to being in totality was the preservation of the a priori structure in which the world appears to us and through which we discover individual differences in the world. Here, the explanation provided by Patočka is much more fragmentary and much less satisfactory than in the field of ethics.

Patočka's attempt to characterize human existence primarily in terms of negation may have succeeded in avoiding ethical relativism and, to a limited extent, a subjectivist conception of the world, but it comes at a high price. The human being distances himself or herself from the world and becomes a homeless stranger in an indifferent world. While Bergson, thanks to his positive account of being (which implies his critique of absolute nothingness) can claim "we feel ourselves no longer isolated in humanity, humanity no longer seems isolated in the nature, that it dominates," ${ }^{71}$ the philosophy of the negative absolute leaves the individual "at a distance from reality in its totality" and from individual things that are, taken in themselves, devoid of any meaning. Patočka's attempts to integrate consciousness into the worldwhether by accepting the relativity of life's ends or by claiming that individual distinctions emerge from total negation-are more a symptom of a wrong starting point than a project yet to be completed.

Nevertheless, we can make good use of Patočka's critique of Bergson. The reason why Patočka distrusted Bergson's abolition of the problem of nothingness is that he considered experiences of "tension," "asperity," "obstacle" 72 or the "capacity to encounter and withstand resistance"73 to be necessary ingredients of existence. Though I believe that this intuition, which guides him in his critique of Bergson, is correct, this critique needs not be translated into a defense of the absolute character of negation as a fundamental feature of consciousness. What does remain absolute in a sense is the unmediated distinction between the positive and the negative, between "yes" and "no," which applies to some of our experiences. Without depriving ourselves of the absolute, we can return from the "yes" and "no" uttered over being in totality to the "yes" and "no" we utter within being when we say yes or no to particular things and possibilities. There are significant life choices and evaluative acts concerning private and public life and even cognitive acts which are formulated as non-indifferent and in a sense absolute-namely, a sharp difference between "yes" and "no."74 Many of our choices and evaluations though are matter of degree and thus fall more under the "distinguishing negation" than under the "negation of contradiction." It would obviously be an exaggeration to say that we make sharp choices and adopt clear-cut positions all the time, but it would be equally wrong to say 
that such choices are never encountered or even extremely rare. The absolute resides neither in fusion with the "élan vital," nor in our distance from being, but emerges from time to time in the form of the capacity to make a fundamental, non-relative difference between options which are contradictory. The outcome of Patočka's reflections on existence and negativity, I believe, is not the absolute of negation but the absolute of difference. Perhaps he would be willing to redefine the consciousness, which he conceived of as the capacity of negation, as the capacity of difference instead. It is not negation, but difference that absolutely matters.

This article is part of a research program conducted at Faculty of Arts, Charles University in Prague and funded by the European Regional Development Fund project "Creativity and Adaptability as Conditions of the Success of Europe in an Interrelated World" (No. CZ.02.1.01/0.0/0.0/16_019/0000734).

1 Among the more comprehensive works from this period is Jan Patočka, Věčnost $a$ dějinnost [Eternity and Historicity] (Prague: OIKOYMENH, 2007), of which Patočka published only the first chapters in Czech (1948); the voluminous "Philosophical Diaries, 1945-1950" (unpublished); and the university lectures "Socrates" (1947) and “Plato" (1948). Patočka develops his own philosophical position primarily in Eternity and Historicity, the "Philosophical Diaries," and several shorter manuscripts to which I will refer in due course. The essay "Negative Platonism" (1953) is also part of this "negative" phase in Patočka's thought. See J. Patočka, "Negative Platonism: Reflections concerning the Rise, the Scope, and the Demise of Metaphysics-and Whether Philosophy Can Survive It," in Jan Patočka: Philosophy and Selected Writings, ed. and trans. Erazim Kohák (Chicago: University of Chicago Press, 1989), 175-206.

2 Diaries, 13.IV.1947. I cite Patočka's "Philosophical Diaries" only using the date of the particular entry. I am very grateful to the members of the Jan Patočka Archive for the opportunity to read the transcript of the Diaries. A French translation of the Diaries has been published as Jan Patočka, Carnets philosophiques 1945-1950, trans. from the Czech by Erika Abrams (Paris: Vrin, 2021).

${ }^{3}$ Diaries, 13.IV.1947; also 16.VIII.1947.

${ }^{4}$ See Věčnost a dějinnost, 22-23. See also Diaries, 15.V.1947.

${ }^{5}$ Diaries, 11.III.1947.

${ }^{6}$ See Věčnost a dějinnost, 23; also Diaries, 18.IV.1947.

${ }^{7}$ Diaries, 7.VII.1947.

${ }^{8}$ Diaries, 7.IV.1947.

${ }^{9}$ Diaries, 25.XI.1946. 
10 J. Patočka, "Nicota, absolutní pozice a zápor" [Nothingness, the Absolute Position and Negation], in J. Patočka, Sebrané spisy 3 [Collected Works 3], (Prague: OIKOYMENH, 2002): 652-70. With the help of related entries from the Diaries, we may reasonably deduce that "Nothingness, the Absolute Position and Negation" was written in 1947 or early 1948 (in the Diaries, the last reference to the problem of negation in Bergson is from May 2, 1948).

11 Jan Patočka, The Natural World as a Philosophical Problem, trans. Erika Abrams (Evanston, IL: Northwestern University Press, 2016), 114. On Patočka's interest in philosophy of life at this time, see Ludger Hagedorn, “'Quicquid Cogitat”: On the Uses and Disadvantages of Subjectivity," in The Phenomenological Critique of Mathematisation and the Question of Responsibility, ed. Ivan Chvatík, Lubica Učník, and Anita Williams (Dordrecht: Springer, 2015), 89-104.

12 See Filip Karfík, “Die Odyssee des endlich gewordenen Absoluten: Patočkas systematische Versuche zwischen 1936 und 1964," in Unendlichwerden durch die Endlichkeit: Eine Lektüre der Philosophie Jan Patočkas (Würzburg: Königshausen \& Neumann, 2008), 36-43.

${ }^{13}$ Henri Bergson, Creative Evolution, trans. from the French by Arthur Mitchell (New York: Random House, 1944): 323.

14 Bergson, Creative Evolution, 321, or L'évolution créatrice, in Oeuvres (Paris: Pléiade, PUF, 1970): 746.

15 Bergson, Creative Evolution, 313.

${ }^{16}$ Bergson, Creative Evolution, 314.

17 Bergson, Creative Evolution, 323.

${ }^{18}$ Bergson, Creative Evolution, 308 and 322. See also Bergson, "The Possible and the Real," in Key Writings, ed. Keith Ansell-Pearson and John Ó Maoilearca (New York: Continuum, 2002): 227.

${ }^{19}$ Bergson, Creative Evolution, 324.

20 Patočka, “Nicota, absolutní pozice a zápor," 652.

${ }^{21}$ Patočka, "Nicota, absolutní pozice a zápor," 653-54.

22 Patočka published a short criticism of Sartre in 1947 under the title "Pochybnosti o existencialismu" [Doubts concerning Existentialism], in Sebrané spisy 6 [Collected Works 6], (Prague: OIKOYMEN, 2008), 322-26. He developed a more sustained critique of Sartre in his Eternity and Historicity (chap. XII) and the Diaries.

23 Patočka, “Nicota, Absolutní pozice a zápor," 659; see also “Pravda, negativita, svoboda" [Truth, Negativity, Freedom], in Sebrané spisy 3 [Collected Works 3], 672. The essential negativity of human consciousness is transformed into a "new 
formalism." In a similar sense also Patočka, Věčnost a dějinnost, 26-27; Diaries, 24.VII.1947.

24 Patočka, “Nicota, absolutní pozice a zápor,” 657. See also Patočka, Diaries, 28.VII.1947: "The non-actual throws its web of meanings over the actual and tries to capture them in it"; see also Patočka, Věčnost a dějinnost, 104.

25 Patočka, "Nicota, absolutní pozice a zápor," 657.

${ }^{26}$ Patočka, “Nicota, absolutní pozice a zápor," 657-58.

27 Patočka, "Nicota, absolutní pozice a zápor," 665.

28 Bergson, "The Perception of Change," in Key Writings, 252 and 264.

29 Patočka, Diaries, 14.I.1948. See also “Nicota, absolutní pozice a zápor," 664: Patočka criticizes Bergson for advocating the "fiction of an utterly passive spirit."

30 Patočka, “Nicota, absolutní pozice a zápor," 662.

31 Patočka, “Nicota, absolutní pozice a zápor," 664.

32 See also Patočka, Diaries (7.IV.1946): perspective is "one of the great speculative experiences," showing us that "in the finite the non-finite is given."

33 Patočka, "Nicota, absolutní pozice a zápor," 662.

34 Patočka has additional reasons for rejecting Bergson's complex reconstruction of negative judgment. He observes that Bergson's negative judgment retains an element of non-determinacy (a negative judgment points out that positive judgment must be replaced by another positive judgment, but does not specify which one). Consequently, Bergson has not eliminated negation in the form of indeterminacy; see Patočka, Diaries, 1.VII.1947.

35 Patočka, “Nicota, absolutní pozice a zápor,” 661.

36 Patočka, “Nicota, absolutní pozice a zápor," 656. See also Patočka’s observations on the negative character of suffering, pain and illness: "here the person herself does not perform the movement of reaction against the immediate, but is thrown into it against her will" (Diaries, 2.II.1947).

37 Bergson, Creative Evolution, 323.

38 Bergson, Creative Evolution, 312.

39 Patočka, “Nicota, absolutní pozice a zápor," 661.

40 Patočka, The Natural World as a Philosophical Problem, 5.

${ }^{41}$ Bergson, Creative Evolution, 322.

42 Patočka explicitly observes: "the whole-captured only negatively”; Patočka, “Zápor a nicota" [Negativity and Nothingness], in Sebrané spisy 3, 670. See also Patočka, Negative Platonism.

43 Diaries, 31.I.1948.

44 Diaries, 11.III.1947. 
45 Patočka, Věčnost a dějinnost, 112.

${ }^{46}$ Diaries, 29.I.1947. See also Věčnost a dějinnost, 23-24.

47 Diaries, 18.IV.1947.

48 Diaries, 19.IV.1947.

${ }^{49}$ Diaries, 20.III.1947.

50 Patočka, Věčnost a dějinnost, 113.

${ }^{51}$ Patočka, “Nicota, absolutní pozice a zápor,” 655. See also Věčnost a dějinnost, 88; the totality of being "arises only by the fact that the negation of being stands against being. The negation of being is total."

52 Patočka, "Nicota, absolutní pozice a zápor," 655.

53 Patočka, “Nicota, absolutní pozice a zápor," 665.

${ }^{54}$ Diaries, 16.VII.1947.

55 Patočka, “Nicota, absolutní pozice a zápor,” 666. See also Patočka, Diaries, 28.VII.1947: "Existences are there, but only on the basis of a fundamental protest against a purely objective, given, ready-made being."

${ }^{56}$ Patočka, “Nicota, absolutní pozice a zápor," 656; see also “Zápor a nicota," 669. In the manuscript "Pravda, negativita, svoboda," which exists also in Italian translation, Patočka is less confident in calling the distinction a negation at all. The qualitative difference of two shades of red is not really grasped by saying that they are not the same red. See "Verità, negazione, libertà," in Jan Patočka: Platonismo negativo e altri framenti, ed. and trans. by Francesco Tava (Milan: Bompiani, 2015), 379-81.

57 Patočka, “Zápor a nicota," 669.

58 See Patočka, “Nicota, absolutní pozice a zápor,” 670; “Pravda, negativita, svoboda," 673; Věčnost a dějinnost, 112. In the Dairies, Patočka calls this "my theory of self-consciousness as genuinely negative" (21.VIII.1947, also 12.VII.1947). The fact that at the same time, for him, transcendence is something that "we perform" ("Nicota, absolutní pozice a zápor," 666) does not preclude the possibility that it might be a necessary structure of consciousness. We are not at liberty not to perform it.

${ }^{59}$ Patočka, Věčnost a dějinnost, 106-7.

${ }^{60}$ Diaries, 8.VI.1947.

61 Patočka, Věčnost a dějinnost, 106-7.

${ }^{62}$ Patočka, Diaries, 12. VII. 1947. "Consciousness therefore poses itself by the mere denial of objecthood and must be there in every posing of objecthood." On this topic see Martin Ritter, "Basically Negative Being in the World," in Into the World: The 
Movement of Patočka's Phenomenology (Cham: Springer 2019), 50: "the given Patočka speaks of . . . resembles the Fichtean not-I."

63 Patočka, “Nicota, absolutní pozice a zápor," 660.

64 It can be objected that Patočka's position does imply certain decision or certain global option: against the fragmented life and in favor of a unified one. Such a global decision would be close to Heidegger's Entschlossenheit. We cannot pursue this any further here. The question would be: how can such a global decision be conceived of as a decision we do within being (and not over being)?

${ }^{65}$ See Patočka, "Studie o času I" [Study of Time I], in Sebrané spisy 3 [Selected Works 3]: 639. For criticism of Patočka on this point, see Pavel Kouba, "Time in "Negative Platonism," ' in Učník, Chvatík, and Williams, eds., The Phenomenological Critique of Mathematisation and the Question of Responsibility, (Berlin: Springer, 2015), 79-88. See also Ritter, "Basically Negative Being in the World."

66 Patočka may be right in stating that negation is "something original," that is, it cannot be derived from the given. But it is a long way from this observation to the claim that negation "presupposes the transcending of the actual reality, and thus of all givenness." Patočka, "Nicota, absolutní pozice a zápor," 663.

67 Jean-Paul Sartre, Being and Nothingness, trans. from the French by Hazel E. Barnes (New York: Washington Square Press, 1984), part I, chapter 1/V, and part II, chap. 3/II ("Determination is Negation").

68 "Negations within the existing entities lead to negation over being; negations within beings are only occasions for the negation over being to flash through. . . . Negative relations in objective entities as mere reminders, as the only link between the two, between the absolute and the relative." Patočka, "Zápor a nicota" [Negation and Nothingness], 670.

69 Patočka Věčnost a dějinnost, 107-8.

70 See Kouba, "Time in 'Negative Platonism,'” 83 and 85 . See also Ritter, “Basically Negative Being in the World," 49. Ritter rightly observes that by conceiving of the given as the "not-I," Patočka "does not fully appreciate the given" and his analysis of the given remains far below the level achieved by Husserl. It seems, that Patočka was aware of this flaw, for he notes in the Diaries that further distinctions have to be made, such as the one between the "objective" and the "actual" (and that the negation of the "actual" differs from the negation of the objective), see Patočka, Diaries, 29.VII. and 31.VII.1947.

${ }^{71}$ Bergson, Creative Evolution, 295.

72 Diaries, 11.III.1947.

73 Diaries, 15.VII.1947.

74 To call them negative only would be a reduction. They imply negation as their 